\title{
Histological Changes in the Gonads of the American Mink During Postnatal Development
}

\author{
Krystyna ZALESKA-FRELJAN
}

\begin{abstract}
Zaleska-Freljan K., 1976: Histological changes in the gonads of the American mink during postnatal development. Acta theriol., 21, 21: 287-298 [With Plates VII-IX]

Studies were made on 79 individuals of the American mink Mustela vison (S chreber, 1777), divided into 5 grops: 1-10 day old, 3-6 week old, 7-7.5 month old and 10 month old, and on females 11 month old. The process of development of the gonads is not complete at the time of the animal's birth. On the first and on the second day post partum the residues of sterile medullary sex cords were observed in females, inception of the process of oogenesis on the 4th day p.p., first interstitial cells from the cells of medullary cords on the 6th day p.p. and from the internal capsule of atretic follicles in 7-7.5 month old females, and the first corpora lutea and albuginea in individuals 11 month old. Metamorphosis of cells of the sex cords into Sertoli cells and occurrence of 2 types of Leydig cells were observed in males $1-10$ days post partum, the first primary spermatocytes - in 7-7.5 month old males, and all stages of spermatogenesis in 10-month old males. In males in which the testes had not yet descended the final stage of spermatogenesis was formed by primary spermatocytes.

[Dept. Anim. Physiol., Univ. Warsaw, Żwirki i Wigury 93, 02-089 Warszawa, Poland.]
\end{abstract}

\section{INTRODUCTION}

Although a considerable amount of information has been obtained on reproduction in mink, only a smaller number of studies have so far been made of the anatomy and histology of the genital organs of these animals, in particular of their gonads, and such studies have hitherto been made solely on animals several months old or sexually mature animals. The morphology of genital organs in the female mink has been examined by: Hanss on (1947), Enders (1952) and by Enderses (1963) as well as by Abramov (1961). Onstad (1967) and Bostrom (1968) carried out histological and physiological studies of the testes. Heidt (1970) compared the development of Mustela nivalis Linnaeus, 1766 and Mustela vison ( $\mathrm{Schreber}, 1777$ ) and other species of North American mink. 
The purpose of the present study is to examine the changes taking place in the histological structure of the ovaries and testes of the American mink directly after birth. Examination was also made of changes in the gonads of adult females and males not exhibiting any sexual urge during the oestrus.

\section{MATERIAL AND METHODS}

Gonads were taken from 79 American mink, $M$. vison obtained from fur farms at Kawęczyn, Skolimów and Pruszków (Table 1). Some of the 11-months old females had been covered by males, and the remainder, which did not exhibit any manifestations of sex urge, were not covered. The animals were killed by administering succinilocholin and exsanguination.

Table 1

Number of females and males examined.

\begin{tabular}{|c|c|c|c|}
\hline Age & $\begin{array}{l}\text { No. of } \\
\text { females }\end{array}$ & $\begin{array}{l}\text { No. of } \\
\text { males }\end{array}$ & Datum \\
\hline 1 day & 3 & 2 & May $12,15,1971$ \\
\hline 2 days & 1 & 2 & May 12,1971 \\
\hline 3 days & - & 3 & May 13,1971 \\
\hline 4 days & 3 & - & May 13,1971 \\
\hline 5 days & 1 & 2 & May 14,1971 \\
\hline 6 days & 3 & - & May 14,1971 \\
\hline 7 days & 3 & - & May 15,1971 \\
\hline 8 days & 2 & 1 & May 15,1971 \\
\hline 9 days & 1 & 2 & May 17,1971 \\
\hline 10 days & 2 & $\overline{1}$ & May 17,1971 \\
\hline 3 weeks & 1 & 1 & June 4, 1972 \\
\hline 4 weeks & 1 & 1 & June 4, 1972 \\
\hline 5 weeks & 2 & - & June 4,1972 \\
\hline 6 weeks & 1 & 1 & June 4,1972 \\
\hline $7-7.5$ months & 7 & 4 & Dec. 12,1971 \\
\hline 10 months & 5 & $3^{*}$ & Febr., 22, 26, 1972 \\
\hline 11 months & 12 & - & March 23, 24, 1972 \\
\hline
\end{tabular}

* Plus four testiconds.

The gonads were fixed in Bouin's and Baker's fluid (B a giński, 1969). The sections obtained from them were embedded in paraffin, sectioned to $4 \mu$, stained with Harris's hematoxylin and eosine and by Mallory's method and, in order to discover lipids, the gonads were treated with $3 \%$ solution of bichromate of potassium at a temperature of $4^{\circ} \mathrm{C}$ and stained with Sudan III after Ciaccio (B ag i ńs k i, 1969).

\section{RESULTS}

\section{Histological Structure of the Ovary}

The surface of the ovary in the mink is covered with a thin layer of epithelium and under it membrana albuginea. A distinct boundary between the cortical part and medulla can be seen in the cross-section of the ovary. 
In the cortical part of the ovary in 1- and 2-day old mink there is an accumulation of gonocytes in the form of nidi ovorum. A large number of the gonocytes undergo degeneration (Photo 1, Plate VII).

The ovarian stroma of the medulla forms loose connective tissue, surrounded by the residue of sterile sex cords, which penetrates into the space between nidi ovorum, and also into the region of residual sex cords, forming several partitions between them. Long branching canalici with two-layer walls - the inner-epithelial and outer-connective tissue - can also be seen in the medulla of the ovary. The remains of the pronephros can be seen near the hilum of the ovary, but these are not observed during the later development of the gonad.

Oogonial cells and primary oocytes occur in nidi ovorum in the ovarian cortex of 4-day old females. Some of the primary oocytes enter into prophase I of the first meiotic division (up to the pachytene stage of meiosis). A large number of oogonia, particularly those lying in accumulations near each other, undergo degeneration in nidi ovorum. The nuclei of degenerating oogonia are characterized by usually dense chromatine. Under the external cortical part with nidi ovorum the first stage of formation of primordial follicles can be seen (Photo 2, Plate VII).

In the medullar part of the ovary canalici with a lumen continue to occur. Proliferation of cells of the canal walls can be seen. These canalici can be observed in all newborn females up to the 5 th day inclusive of development.

Jn the external cortical part of 5 and 6-day old females nidi ovorum containing oocytes and scanty oogonia occur under membrana albuginea. Some of the oocytes are in the prophase of the first meiotic division (up to the diplotene stage of meiosis). Numerous primordial follicles surrounded by one or two layers of follicular cells and small growing follicles are encountered in the internal cortical part. Some free oocytes and oocytes lying inside follicles exhibit degenerative changes, evidence of which is the uniform dark staining of the whole of the cell nucleus. Lipids appear in the cytoplasm of growing oocytes (Photo 3, Plate VII).

The first interstitial cells begin to form in the medullar part of the ovary in 6-day old mink. They form from cells of sterille sex cords in process of metamorphosis. Lipids are present in the cytoplasm of interstitial cells. Rete ovarii had grown, from the pronephros, into the interior of the gonad from the hilar side.

On the seventh, eight and ninth day of life accumulation of oocytes and follicles with $1-3$ layers of cells occur in the cortical part. It is not until the seventh day that the third layer of cells of membrana granulosa begin to appear in the follicles. A considerable number of oocytes degenerate. A surrounding layer of connective tissue occurs round the 
follicles, which in the future forms theca interna and externa of the follicles. Formation of interstitial cells arranged in the form of distinctly separated accumulations is still observed. Rete ovarii englarges and branches.

On the tenth day of development thickening of membrana albuginea is observed. Formation of the 4th and 5th layer of cells of membranal can be seen in the largest follicles. Rete ovarii greatly develops (Photo 4 and 5, Plate VII).

A thin cortical layer, in which accumulations of primordial follicles, growing follicles of various sizes and Graafian follicles occur, is observed in the ovary of mink $3-5$ weeks old. The Graafian follicles have a two-layer zone - internal and external. The follicles adhering to interstitial tissue degenerate.

Two distinct layers can be seen in the ovarian medulla, the external layer consisting of aggregations of interstitial tissue cells containing lipids and the internal layer of connective tissue, in the centre of which rete ovarii can be seen. Both layers are well vascularized. The residues of sterile medullary sex cords are situated on the boundary between interstitial and connective tissue.

In females 5 and 6 week old it was found, in addition to the changes so far observed in development of the gonads, that in some places on the surface of the ovary epithelium, together with membrana albuginea, thrusts into the depth of the cortex and medulla, forming characteristic hila. In one 6 week old mink the branching hila were observed to connect with intramedullar canalici of rete ovarii. Interstitial tissue develops strongly in the medullar part.

In females aged $7-7.5$ months single primordial follicles, surrounded by a single layer of follicular cells, are observed in the external layer of the ovary under membrana albuginea. In the deeper parts of the cortex there are growing follicles surrounded by $2-5$ layers of cells of membrana granulosa. They contain an oocyte surrounded by zona pellucida. Maturing follicles also occur at an even greater depth in the ovarian cortex, the oocyte of these follicles being surrounded by a greater number of cells of membrana granulosa. Light-coloured irregular spaces filled with liquor folliculi appear between these cells.

Only 1-3 large Graafian follicles were found in the cortex of the ovaries in the females examined (Photo 6, Plate VII). The surface of the ovary lies close to the fimbriae of the tuba uterina in the place where the Graafian follicle is markedly convex. Some growing and maturating follicles become atretic. Lipids occur in large numbers in the cytoplasm of cells in the internal layer of Graafian follicles. They are also present in the cytoplasm of the oocytes of primordial and growing follicles. 
The more external part of the medulla is occupied by strongly developed interstitial tissue, in which bands of interstitial cells and blood vessels occur (Photo 7, Plate VIII). These are large, polygonal, with a spherical nucleus. There are lipids in their cytoplasm. Formation of the second generation of intersititial cells, formed from theca interna of atretic follicles, is observed for the first time in mink from 7-7.5 month old. The ovarian medulla consists in these mink of the residue of rete ovarii, connective tissue and blood vessels.

In females 10 months old considerable growth of interstitial tissue continues to be observed, the cells of which almost completely fill the ovarian cortex. Between them there are larger and smaller sinusal blood vessels. The exterior layer of the cortex is limited to a narrow band only beneath membrana albuginea. A small number of primordial follicles and growing follicles with lipids in the cytoplasm of oocytes occur in it. Single Graafian follicles are encountered on the periphery of the cortex in a few ovaries only. The cells of stratum granulosum present inside large follicles are very high and almost cylindrical. There are lipids in the cytoplasm of these cells.

Formation of atretic follicles was also observed. During the initial phase of their formation cells of membrana granulosa are observed to penetrate into the cavity of the follicle and to fill it with these cells. The oocyte surrounded by zona pellucida is thrust on to the periphery of the follicle. A progressive process of vacuolar degeneration can be observed in the cytoplasm of the oocyte, this cytoplasm losing its uniform character. Several small vacuoles, with bands of cytoplasm between them, are observed there. There is still a nucleolus in the nucleus of the oocyte.

In the later stage of atresia the cells of membrana granulosa fill the whole cavity of the follicle containing the degenerating oocyte. It is by now impossible to distinguish the different elements of the cell in it, and the zones of the follicle also disappear. A branching network of blood vessels forms round the follicle.

In yet another phase of atresia cells of membrana granulosa are not observed at all, but interstitial cells can be seen surrounding the degenerating oocyte, arranged in accumulations surrounded by zones of connective tissue. There are often large blood vessels round structures of this type (Photo 8, Plate VIII).

In females 10 month old the process of formation of interstitial cells from the cells of theca interna of atretic follicles aiso takes place. In some of the females examined the epithelium, together with membrana albuginea of the ovary, sinks in several places into the interior of the cortex, forming shorter and longer hila in it (Photo 9, Plate VIII). The 
ovarian medulla is distinctly enlarged in comparison with the medulla in mink from 7-7.5 month old. The medulla contains residue of rete ovarii, connective tissue, blood vessels and strongly developed interstitial tissue.

One or more corpora lutea are observed to occur in the cortex of the ovary in females 11 months old. In the case of females which have not been covered these are pseudo corpora lutea. Corpora lutea contain large luteal cells of irregular shape with a spherical nucleus, and a small number of lipids can be seen in their cytoplasm. There are also strands of connective tissue and numerous blood vessels in the spaces between these luteal cells. Corpora lutea are surrounded with capsules of connective tissue and a network of blood vessels varying in size (Photo 10, Plate VIII). Corpora lutea lie in the peripheral part of the ovarian cortex, surrounded by groups of interstitial cells containing lipids. Corpus albicans in cicatrisatione overgrown in the middle of connective tissue was observed in one of the females in addition to corpus luteum and in another, corpus albicans in process of formation (Photo 11, Plate VIII).

Apart from corpora lutea only scanty oocytes, primordial growing and atretic follicles can be seen in the very thin peripheral part of the cortex. Lipidal droplets are found in the cytoplasm of oocytes of primodial and growing follicles. A large number of lipids occur in the cytoplasm of interstitial cells (Photo 12, Plate VIII). Some primordial and growing follicles undergo degenerative changes. No mature Graafian follicles are observed at all. In the cytoplasm of some oocytes dense patches of cytoplasm, corresponding to the location of Balbiani nucleus, occur in growing follicles.

\section{Histological Structure of the Testis}

The testis in day-old males is surrounded by membrana albuginea, on which lies the epithelium covering the surface of the gland. The testis has a fairly compact system of tubuli seminiferi. These tubules already possess a lumen, are straight and not folded (Photo 13, Plate IX). Their interior is filled with gonocytes and cells of the sex cords which undergo metamorphosis into Sertoli cells. Spermatogonia are observed immediately below the membrane itself of the tubules, some of which exhibit degenerative changes, revealed by the dark, uniformly stained nucleus.

The spaces between tubuli seminiferi are filled with interstitial cells and connective tissue cells of a germinal character. Lipids are present in the cytoplasm of some of the interstitial cells. These cells are distributed in well-defined and separated spherical accumulations between tubuli seminiferi of the testis. The second type interstitial cell is formed by cells without lipids in the cytoplasm. 
The residue of the pronephros can be seen near the hilum of the gonad. In day-old males the remains of sex cords formed of epithelial cells can still be seen. During the subsequent 9 days of development these are not encountered. They undergo metamorphosis into simple canalici. During the animal's development these canalici become more strongly folded and elongated (Photo 14, Plate IX). Membrana albuginea of the testis also thickens. The process of descent of the testes ends on the ninth day.

The testis of mink from 3-6 week old is divided into lobules by partitions of connective tissue radiating from mediastinum testis. Tubuli seminiferi surrounded by interstitial tissue are included in the structure of these lobules. The tubules begin to fold and a layer of Sertoli cells and spermatogonia, part of which when in the proliferation period will undergo mitosis, can be seen inside them. Some of them had moved from their own membrane to the lumen of the tubule. Lipids are present in the cytoplasm of interstitial cells lying betiveen the tubules and on the periphery of the gonad directly under membrana albuginea.

The testes of 7-7.5 months old males are surrounded by a thick layer of membrana albuginea. Tubuli seminiferi are arranged compactly. Several primordial spermatocytes were observed in some of the tubules in two males. There were triangular spaces containing Leydig cells of irregular shape and connective tissue cells between the tubules. Lipids are present in the cytoplasm of all Leydig cells. Traces of them occur in the cytoplasm of all primordial spermatocytes.

Males 10 months old are by that time sexually mature. All stages of spermatogenesis are encountered in their tubuli seminiferi - spermatogonia, primary and secondary spermatocytes, spermatides and sperma (Photo 15, Plate IX). Sperm is also present in almost all tubuli seminiferi of the testis of an adult male, and also in the straight tubules, in the rete testis and in the duct of the epididymis (Photo 16, Plate IX). Leydig cells with lipids in the cytoplasm, and also connective tissue cells lie between the tubules.

In the seminiferous tubules of the testes in males with undescended testes there are 1, 2 or at most 3 layers of cells. These are Sertoli cells, spermatogonia and primordial spermatocytes. Some of the primordial spermatocytes enter into the prophase of the first meiotic division. In testicond animals there are no cells in the later stages of spermatogenesis and consequently the lumen of the tubule is usually empty, and only long pseudopodia of Sertoli cells, contacting each other, can be seen in it (Photo 17, Plate IX). Spermatogonia and sepermatocytes are shifted from the lumen of the testicular tubules to those of the epidi- 
dymis (Photo 18, Plate III). In some testiconds there is an increase in the number of Leydig cells. The tubules are completely separated from each other by interstitial tissue. Lipids, similar to those in normal testes, occur in the cytoplasm of Leydig cells. Every male with unilateral cryptorchism has a slightly larger second testis, normally developed, with sperm in the lumen of the seminiferous tubules.

\section{DISCUSSION}

The development of gonads in the mink takes the same course as in other mammals, except that a very number of interstitial cells form in the ovaries. Nidi ovorum observed in the ovarian cortex in newborn mink are also encountered in other mammals, e.g. in rodents. P e ters \& C larke (1974) observed nidi ovorum in the ovarian cortex of dayold individuals of Clethrionomys glareolus and in $1-7$ day old individuals of Microtus arvalis. The small number of Graafian follicles observed in females 7-7.5 and 10 mor.th old was probably due to the degeneration of oocytes in the ovaries in the earlier stages of the females' development. The occurrence of lipids in the cytoplasm of the oocytes may point to a degenerative process.

Females 7-7.5 month old examined in December should normally be in the final month of anoestrus (in accordance with breeders' observations) but the rapid growth of maturing follicles beginning in these females is evidence that the next phase of the sexual cycle - proestrus - begins earlier than usual. This fact was probabaly connected with the earlier onset of a warm spring, and thus with a greater amount of light and warmth - important factors affecting the course of the sexual cycle in animals having one oestrus, among which is the mink. In females 10 month old examined in February the phase of prooestrus is observed as anticipated. Mature Graafian follicles are encountered in some of the ovaries only. The very limited number of primordial oocytes and primordial follicles in the ovarian cortex of the females examined might have been caused by their intensive degeneration and oogonia similar to that observed in mink $1-10$ day old, while the small number of mature Graafian follicles and absence of any symptoms of the oestrus were probably caused by the earlier maturing of the follicles.

The causes of the intensive degeneration of gonocytes (far more intensive than physiological degeneration), oocytes, oogonia and primordial follicles in newborn mink are not known. In order to find the explanation of these symptoms, causing anxiety to breeders, it would be necessary to carry out further observations and at the same time examine the pituitary gland and the gonadotropin content in the blood. 
Two generations of interstitial cells can be observed during the development of ovaries. The first of these is formed from the niedullary sex cords of 6-day old mink. Its genesis is the same as that of cells of membrana granulosa. The second is formed from theca interna of atretic follicles of 7-7.5 and 10- and 11-month old females. P a tzelt (1956) found that interstitial tissue is characteristic of the ovaries of wild predatory animals. Deanesly (1969) observed the appearance of the first cells of this tissue in the medullary layer of the ovary in the ferret as from the 7th day of postnatal development. During the third week of life these cells grow and differentiate into epithelial cells containing lipids. They form glandular lobes round the medullary part. Hansson (1947) found a distinct boundary between the cortex and medulla of the ovary in female North American mink. This boundary forms the interstitial glandular tissue dominating in the microscopic picture. Athias (1920) observed that the interstitial tissue in the gonads of female bats is formed in young animals from connective tissue elements of the ovarian stroma, but in older animals from the cells of theca interna of atretic follicles. Similarly strongly developed interstitial tissue occurs in the ovarian medulla of moles (Talpa europea) (A u m ülle r, 1974).

The canalici observed in the centre of the ovary in mink $1-6$ day old, defined as medullary canalici, disappear in females 6-10 day old. Deanesly (1969) observed the earliest formed rete in the ovarian medulla of the ferret (Mustela putorius furo) on the first day post partum. She distinguished between medullary canalici characteristic of day-old ferrets and the ovarian rete observed in animals $6-16$ days old. Patzelt (1956) describes the medullary canalici of female predatory animals as "testoid «, but states that during development they branch and extend to the primordial follicles, blood vessels and nerves. In adult females lobes of interstitial cells thrust between the tubules of the "testoid".

In 6-day old female minks rete ovarii was observed to penetrate into the medulla of the gonad from the side of the pronephros. The residue of this rete persists in mink 6 week old. In predators and ruminants residue of rete ovarii often occurs, particularly in the region of the mesovarium. They consist of medullary ducts arranged in a network lined with flat or cylindrical often ciliated epithelial cells.

The bulges of the covering epithelium and membrana albuginea into the interior of the ovarian cortex, such as observed in mink 6 week - 11 months old, are similar to those described in the badger (Meles meles) by $\mathrm{Neal} \& \mathrm{Harr}$ is on (1958). In one of the 6-week old mink the branching hila of the ovary were observed to connect with 
the residue of the canalici of rete ovarii. Neal \& Harrison (1958) state that well developed crypts in the surface, surrounded by the covering epithelium, connect with the intraovarian canalici. The significance of such connections is difficult to establish. Bulging of the epithelium into the interior of the cortex has been observed by: $\mathrm{Harris}$ on et al. (1952) in the seal (Pinnipedia) and by Perry (1953) in the elephant (Proboscidea). Harrison \& Matthews (1951) state that the covering epithelium is often drawn into the middle of the ovary in the direction of the membrana albuginea lying beneath it, in the form of small curves, cavities or crypts below the surface.

In male mink, contrary to females, no connection was observed between the early onset of spring and the course taken by the process of spermatogenesis. In male mink $1-10$ day and $3-6$ week old two types of interstitial cells have been found, one of which contained lipids. Onstad (1967) described interstitial cells in male mink 30 day old (i.e. in the youngest of the groups examined). One type was formed by cells with a small, dark, spherical or fusiform nucleus, the second lying between the above - by small accumulations of Leydig cells (characteristic of adult males). In individuals $6-8$ month old the cells of the intertubular tissue were replaced chiefly by Leydig cells. Two such completely separate generations of interstitial cells have been described in a considerable number of mammalian species (On s t a d, 1967) - the first of these is the foetal generation, the second - that forming during the period preceding sexual maturity.

The histological picture of testes in testicond mink is similar to that observed in males 1-10 day old. No secondary spermatocytes, spermatids or sperma were found in the testes of testicond individuals. The causes of cryptorchism in mink are difficult to establish - the condition may be due to underdevelopment of the testiculo-inguinal ligament, and also to reduction in the amount of gonadotropin or other hormonal disturbances. Genetic factors undoubtedly also play an important part here, and therefore individuals exhibiting cryptorchism should be eliminated from stock, even though they might prove fertile in cases of unilateral cryptorchism.

\section{REFERENCES}

1. Abramov M. D., 1961: Razvedenie norok. Gos. Izd. Selskohozjajstvennoj Literatury: 3-175. Moskva.

2. Athias M., 1920: Recherches sur les cellules interstitielles de l'ovaire des cheriopteres. Arch. Biol., 30: 89-92.

3. A u mülle r G., 1974: Zur Feinstruktur des Maulwurfovars (Talpa europaea, L.). Z. Anat. Entwickl. - Gesch. 144: 1-18.

4. Ba giński S., 1969: Technika mikroskopowa. Państw. Wyd. Nauk. 1-732. 
5. B ostrom R. E., 1968: Seasonal changes in testes and epididymides of the ranch mink (Mustela vison). Quart. Bull., Mich. Agr. Expmt. Stat., 50: 538-558.

6. Deanesly R., 1969: Oogenesis and the development of the ovarian interstitial tissue in the ferret. J. Anat., 107: 165-178.

7. Enders R. K., 1952: Reproduction in the mink (Mustela vison). Proc. Amer. Phil. Soc. 96: 691-755.

3. Enders R. K. \& Enders A. C., 1963: Morphology of the female reproductive tract during delayed implantation in the mink. [In: Enders A. C. (ed.), „Delayed Implantation «]. Univ. of Chicago Press; 129-140. Chicago.

9. Hanss on A., 1947: The physiology of reproduction in the mink (Mustela vison Schreb.) with special reference to delayed implantation. Acta Zool. Stokh., 28, 1: $1-136$

10. Harrison R. J. \& Matthews L. H., 1951: Sub-surface crypts in the cortex of the mammalian ovary. Proc. zool. Soc., Lond., 120: 698-712.

11. Harrison R. J., Matthews L. H. \& R oberts J. M., 1952: Reproduction in some Pinnipedia. Trans. zool. Soc., Lond., 72: 437-540.

12. Heidt G. A., 1970: The least weasel Mustela nivalis Linnae us. Developmental biology in comparison with other North American Mustela. Biol. Ser., Publ. Mus. Mich. State Univ., 4, 7: 229-289.

13. Parkes A. S. (ed.), 1956: Marshall's physiology of reproduction. 1, 1: 1-688+ +xix. Longmans, Green \& Co. London, New York, Toronto.

14. Neal E. G. \& Harrison R. J., 1958: Reproduction in the European badger (Meles meles L.). Trans. zool. Soc., Lond., 29: 67-131.

15. Onst ad O., 1967: Studies on postnatal testicular changes, semen quality and anomalies of reproductive organs in the mink. Acta endocr., 117: $1-86$.

16. Patzelt V., 1956: Der Eierstock der Säugetiere und die Phylogenese. Ergebnisse der Anat. und Entwicklungsgeschichte 35: 54-68.

17. Perry J. S., 1953: The reproduction of the African elephant, Loxodonta africana. Phil. Trans., B, 237: 93-149 (cited after Marshall, 1956).

18. Peters H. \& Clarke J. R., 1974: The development of the ovary from birth to maturity in the bank vole (Clethrionomys glareolus) and the field vole (Microtus agrestis). Anat. Rec., 179: 241-252.

Accepted, November 4, 1975.

\section{Krystyna ZALESKA-FRELJAN}

\section{ZMIANY HISTOLOGICZNE GONAD NORKI AMERYKAŃSKIEJ W ROZWOJU POSTNATALNYM}

\section{Streszczenie}

Zbadano 79 norek amerykańskich, w tym osobniki 1-10 dniowe, 3-6 tygodniowe, 7-7,5 i 10 miesięczne oraz 11 miesięczne (tylko samice). Uzyskane wyniki wskazują, że proces rozwoju gonad nie jest zakończony w momencie urodzenia się norek i trwa jeszcze u 10-11 miesięcznych zwierząt.

Gonocyty w gniazdach jajowych kory jajnika i resztki płonnych sznurów rdzenych spotyka się u 1 i 2 dniowych samic (Fot. 1). Proces oogenezy oraz tworzenie się pęcherzyków pierwotnych rozpoczyna się w 4 dniu post partum (Fot. 2). Pierwsze komórki interstycjalne z przekształcających się komórek sznurów rdzennych powstają od 6 dnia p.p. Pęcherzyki Graafa z 2-warstwową torebką występują już w korze 2-6-tygodniowych norek, pęcherzyki atrezyjne u 7-7,5 miesięcznych 
(Fot. 8), ciałka żółte i białawe bliznowaciejące u 11 miesięcznych (Fot. 10 i 1.1). Powstawanie komórek interstycjalnych z torebki wewnętrznej pęcherzyków atrezyjnych obserwuje się u 10 miesięcznych norek. Pozostałości sieci jajnika widoczne są jeszcze w rdzeniu gonady 11 miesięcznych zwierząt.

U 1-10 dniowych samców kanaliki nasienne jądra wypełnione są gonocytami i komórkami sznurów płciowych, które przekształcają się w komórki Sertoliego (Fot. 13). Wyróżnia się 2 typy komórek Leydiga: zawierające lipidy i bez lipidów. W kanalikach nasiennych jąder nielicznych samców 7-7,5 miesięcznych pojawiają się spermatocyty I rzędu, a u samców 10 miesięcznych - wszystkie stadia spermatogenezy (Fot. 15). W kanalikach jąder wnętrów proces spermatogenezy zatrzymuje się z chwilą wytworzenia spermatocytów I rzędu, a czasem u części ty ch spermatocytów w momencie profazy I podziału dojrzewania. Tkanka interstycjalna zajmuje $w$ jądrach wnętrów znacznie większe przestrzenie niż $w$ normalnych jądrach.

\section{EXPLANATION OF PLATES}

Plate VII

Photo 1. Part of the ovarian cortex of a day-old female.

Photo 2. Part of the ovarian cortex of a 4-day old female.

Photo 3. Folliculi crescentes in the ovarian cortex of a 5-day old female.

Photo 4. Medulla and part of the ovarian cortex of a 10-day old female.

Photo 5. Medulla of the ovary of a 10-day old female.

Photo 6. A mature Graafian follicle of the ovary of a 7-month old female.

\section{Plate VIII}

Photo 7. Part of the ovarian cortex in a 7-month old female.

Photo 8. Folliculus atreticus in the ovarian cortex.

Photo 9. Part of the ovarian cortex in a 10-month old female.

Photo 10. Corpus luteum in the ovarian cortex of an 11-month old female.

Photo 11. Corpus luteum and corpus albicans in cicatrisatione in the ovarian cortex of an 11-month old female.

Photo 12. Part of the ovarian cortex in a 11-month old female.

\section{Plate IX}

Photo 13. Tubulus seminiferous of the testis in a 2-day old male. Photo 14. Testis of a 9-day old male.

Photo 15. Tubulus seminiferous of the testis in a 10-month old male.

Photo 17. Tubuli seminiferi of the testis in a 10-month old testicond male.

Photo 18. Ductus epididymidis in a 10-month old testicond male.

Abbreviations: a - folliculus, i - f. atreticus, c - caput epididymidis, ca - corpus albicans in cicatrisatione, ce - cauda epididymidis, cl - corpus luteum, co cumulus oophorus, cS - cellulae Sertoli, d - lumen ducti epididymidis, e - stratum epitheliale tubulorum retis ovarii, $\mathrm{f}-$ fossa in cortice ovarii, fc - folliculi crescentes, $\mathrm{fm}$ - funiculi medullares ovarii, i - tela interstitialis, ic - integumentum telae coniunctivae circumflexens accumulationes cellularum telae interstitialis, 1 - cellulae luteinice, $\mathrm{lpi}$ - lipidi in cytoplasmate cellularum telae interstitialis, lpo - lipidi in cytoplasmate ovocyti, $\mathrm{m}$ - mediastinum testis, $\mathrm{n}$ - nidi ovorum cum gonocytis normalibus, nd - nidi ovorum cum gonocytis in degeneratione, o- ovocytum cum corona radiata, oI - ovocyta I in prophasa I divisions maturationis, od - ovogonia in degeneratione, on - ovogonia normalia, $\mathrm{p}$ - folliculi primordiales, $\mathrm{pS}$ - pseudopodia of Sertoli cells, s - spermatogonia, sI - spermatocyta I, sII - spermatocyta II, sd - stratum coniunctivum tubulorum retis ovarii, sd - spermatidae, sg cellulae strati granulosi folliculi crescentis, sp - spermia, t - tubuli retis ovarii, tc - tela coniunctiva, te - theca folliculi externa, ti - theca folliculi interna, ts - tubuli seminiferi, v - vas sanguineum. 


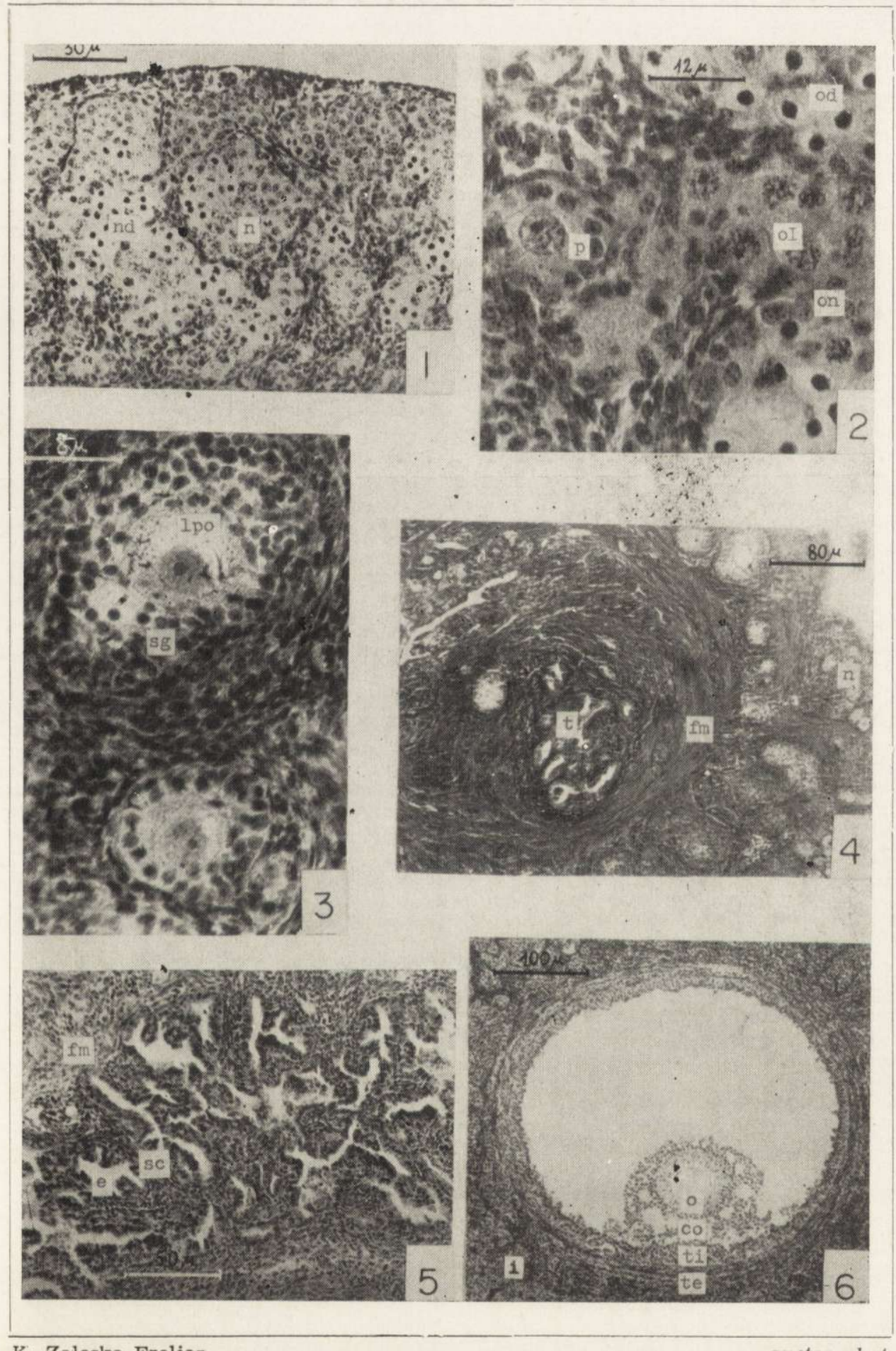

K. Zaleska-Freljan 
ACTA THERIOLOGICA, Vol. XXI, 21.

Plate VIII.
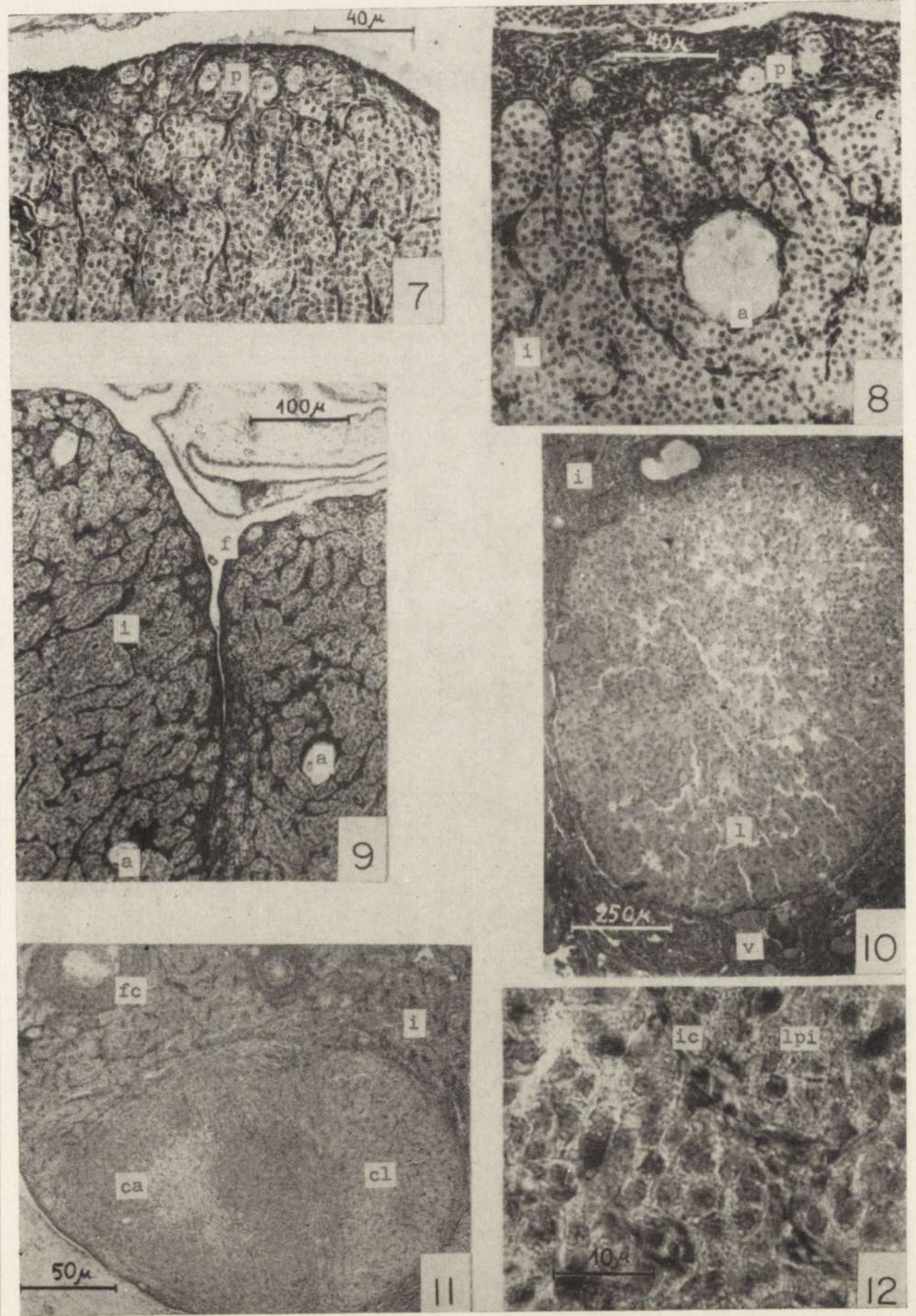

K. Zaleska-Freljan

auctor phot. 


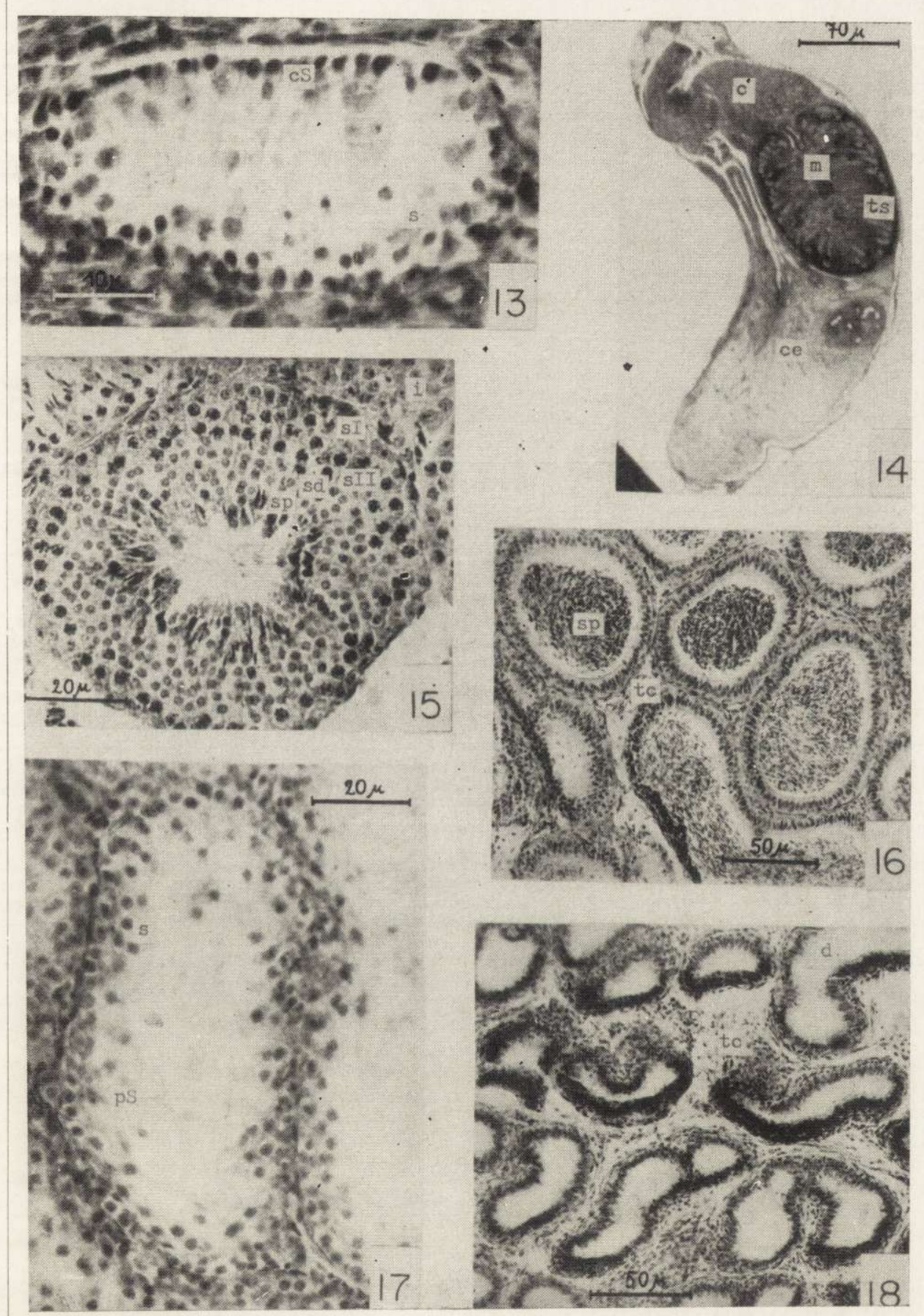

K. Zaleska-Freljan auctor phot. 